\title{
Information as Work and as Value
}

\author{
Marcos Dantas \\ Universidade Federal do Rio de Janeiro, Brazil, mdantas@inventhar.com.br, \\ www.marcosdantas.pro.br
}

\begin{abstract}
This article suggests an approach to Marx's capital valorisation theory supported by a dialectical information theory as developed by physicians, biologists and also communication theorists during the second half of the 20th century. It suggests that it is possible to link the basic concepts of information, as science has established them, to Marx's basic concepts of capital. Based on this foundation, this article also tries to explain how capital, in its development, has evolved to discharge redundant or repetitive jobs but has become increasingly dependent on random or creative ones. Because of this circumstance, in its present stage, the capitalist production process creates value in many concrete forms of semiotic information. Because information cannot be reduced to the status of a commodity, as the theory explains, capitalist states and corporations are improving and hardening intellectual property laws in order to appropriate the information value created by "creative" or "artistic" work.
\end{abstract}

Keywords: Value, information, negentropy, communication, capital, Marx, random work, redundant labour, informational rents.

Acknowledgement: The author is grateful to the critical comments and suggestions of the reviewers, the help and support of Denise Moura and Gabriela Raulino, and the contribution by the editors for the quality of the final text.

History itself is a real part of natural history of nature developing into man. Natural science will in time incorporate into itself the science of man, just as the science of man will incorporate into itself natural science: there will be one science. (Marx 1844)

In a work originally published in 1950, Norbert Wiener, the 'father' of Cybernetics, may have been the first to warn that "information" could not be reduced to a commodity, even while admitting that to be its destiny in capitalist society (Wiener 1950). In another pioneering work, economist Kenneth Arrow equally demonstrated the difficulties that would arise from the reduction of "information" to a commodity, claiming that it should be treated as a "public resource" (Arrow 1977/1962). Both Wiener and Arrow were anticipating the new and serious institutional and political problems linked to the appropriation of the value of 'information' and 'knowledge' that may be in the core of the contradictions of capitalism this century. They also anticipated a great theoretical challenge, since economic theories, both classical and neoclassical, excluded 'information' and 'knowledge' from their formulations, or rather considered them as presupposed elements.

As Rullani asserts, 
Knowledge certainly has use value [...] but it doesn't have a cost value that can be used as a reference to determine the exchange value and that works as marginal cost (neoclassic theory) as well as reproduction cost (Marxist theory). Indeed, the production cost of knowledge is highly uncertain and, above all, is radically different from its reproduction cost. Once the first unit has been produced, the cost to reproduce other units tend to zero (if the knowledge is codified) [....] The exchange value of a commodity which reproduction cost is null inevitably tends to zero $(2000,89-90)$.

In order to understand the logic that operates behind this accumulation regime, which I will call information-capital, we need to rethink the place of concrete work in political economy. Marx realised that if human work results, on one hand, in fatigue that needs to be tackled by means of good nutrition, hours of sleep, and leisure time; on the other hand, it also results in creation, in modification of the matter or the environment, in something different from what existed before work was started. During the same working time, the worker's physical and mental wear occur alongside some alteration of reality to which they have incorporated their idea or project. In Marx's elaboration, as will be discussed in detail later on, during the same working time there is an exchange between the worker and his or her object: one's loss, expressed by his or her fatigue, allows another's gain, expressed by the transformation performed. There is also an equivalent gain that corresponds to that loss: the salary. The transformation of the object also corresponds to many other losses, such as rubbish, energy consumption, and so on. This type of exchange, being constitutive of life, is inherent to the relation of every living being with the nature around it.

In the time of Marx, one of the poles of this exchange was already well-known by science, thanks to the studies of Carnot, Clausius and Maxwell that formalised it through the Laws of Thermodynamics and the concept of entropy: the measure of the natural tendency of every organised system towards heat dissipation, disorganisation and loss of capacity to provide work. The other pole only began to be studied and understood better in the 20th century, especially after the Second World War: information, or a process that, under certain conditions and limits, allows a system to recover part of the dissipated heat, sustain a certain degree of relative order and thus retain its capacity of providing work.

Influenced by Shannon (1948), the construction of a scientific information theory has followed two different paths as described and discussed by Sfez (1992/1988): "representative communication" and "expressive communication". The first, Sfez says, is Cartesian, dualist, atomist, with formal logic, and totally operational for engineering. Thanks to this theoretical axis we have all the modern development of digital technologies. The second is Spinozian, monist, organicist or systemic, with dialectical logic: it was developed first by cybernetics scientists such as von Foerster (1980), biologists such as Henri Atlan (1992), psychologists and communication theorists such as Gregory Bateson and his Palo Alto School (Bateson et al. 1981; Bateson 1987). To this axis, we can add Anthony Wilden (2001), Robert Escarpit (1991), Vieira Pinto (2005), and Dantas (1996; 1999; 2007; 2012), who have all established links to Hegelian and Marxian dialectics. Nowadays, we can consider information theory, in its two axes, as well-established and consolidated, although of course it remains in continuous evolution. 
The first section of this article exposes information theory's basic aspects - mainly those aspects that are significant to the Marxian political economy debate. The second section deals with Wiener's or Arrow's warnings, but now from the perspective of Marx's Value Theory, enlightened by information theory. Doing this, the article argues that the basic Marxian categories are closely linked to information theory. For instance, as we will see, the distinction Marx made between "living labour" and "dead labour" is quite similar to the distinction between "information" and "negentropy" as formulated by Brillouin (1988) and Atlan (1992).

After these two first theoretical items, the final two sections discuss some aspects of the capitalist information society we live in.

\section{Information and Work}

Information is an energy modulation that causes something different in a given system and produces within that system some kind of oriented action, if there is an agent in it that is able and interested in capturing and processing the senses or significations of that modulation. Therefore, the information is not 'in' the object, neither is it in the agent. It is found in the interaction, in the relation established by physicochemical phenomena between agents driven by their purposes, and the forms that are highlighted in the environment and duration of the action.

This brief statement aims to summarise and synthesise the investigations and formulations of a broad range of authors whose theories and demonstrations, including convergences and divergences, could not be detailed in the space of an article (Atlan 1992; Bateson 1987; Brillouin 1988; Escarpit 1991; Moles 1978; Monod 1976; Von Foerster 1980; Shannon 1948; Singh 1982; Vieira Pinto 2005; Wiener 1950; Wilden 2001; Dantas 1996; 1999; 2001).

We know that any transformation in a system results from the thermally differentiated subsystems that coexist and interact inside it. As established in the Laws of Thermodynamics, there is an inescapable trend of transferring heat from the hotter to the colder subsystems, up to a point where the thermal conditions of the entire system are equalised. The entropy rate will indicate the degree of indifferentiation/disorder or equilibrium of a system in relation to a previous degree of higher differentiation/order, or to a later degree of even higher disorder and equilibrium.

Therefore, if a system is not in thermal equilibrium, it will undergo spontaneous and inexorable chemical or physical transformations. Since these transformations imply the action of parts of the system on other parts, they produce physical and/or chemical work.

However, if parts of the system manage to spontaneously perform a certain amount of work, it is because they retain, at a given initial moment, some capacity to do so. Brillouin (1988) coined the term negentropy, referring to the capacity to perform or provide work: the opposite or negative of entropy. There must be negentropy in order to obtain information:

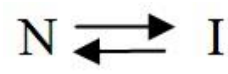

That is what happens when a living organism, having the necessary means for this purpose, is guided by sound or light frequencies, odour molecules, electrical emissions or other variations that may occur in its environment, and then selects and processes them, in order to recover or maintain a certain necessary degree of 
negentropy. Monod (1976) demonstrates that this is how enzymes work, thus clarifying the thermodynamic paradox of life. Every living being performs negentropic or informational work: processing and selecting energy modulations that allow them to identify and capture, within the environment, sources to recover the negentropy that was thermodynamically dissipated. However, as we well know, this work demands 'spending' energy. The limit of this expenditure is given thermodynamically: the recovered negentropy can't be higher than that dissipated in the negentropic work itself (if that were possible, the Laws of Thermodynamics would be revoked). At most, under exceptional conditions the negentropic gain and loss will be equalised. In other words: the gain of negentropy, on one side, is generally 'paid off' by a gain of entropy on the other. Hence, the negentropic efficiency of informational work can be measured by the formula:

$$
\Delta N / \Delta S \leq 1
$$

where $N$ is negentropy and $S$, entropy.

The problem of every negentropic organism is to extract optimal efficiency from its action. Its 'opponent', so to speak, is time: the more time the organism consumes in its negentropic work, the more time it grants to entropy. Its goal, therefore, should be to obtain the maximum possible negentropic efficiency in the shortest time. To 'save time', every organism, through its senses (including the human being with its senses and technological prostheses), is able to cut out a pattern of events distinguished from the background of the environment, through which it realises or differentiates the events that will guide its action. Hence, as highlighted by Bateson, information will be "any difference which makes a difference in some later event" (Bateson 1987, 381).

This pattern of events constitutes a code: a set of forms, noticeable in space and time that offers an agent a certain degree of predictability as to the events that can be perceived through this set of forms. Every code also contains an equally finite set of rules which an agent can use in order to give those events sense, orientations, and meanings. All information is necessarily codified - or it does not constitute information.

A code requires some repeatability and hence predictability in order to be initially recognised. This repeatability is called redundancy, and it allows the agent to establish the degrees of differentiation that are needed for the extraction of meanings or significations contained in the event transmitted through the code. That is, the redundancy allows somebody facing a message with some missing items "able to guess at the missing items with better than random success" (Ibid., 419).

Adopting the principle of logical types by Russell and Whitehead, Anthony Wilden (2001) understands that the apparently shapeless background pattern of the manifestations of light, sound, odour, heat, cold and so on, in which any agent is immersed and to which it doesn't and can't pay permanent attention, constitutes the total class of variety (the set of all possible eventualities, or Redundancy $=0$ ), in which the agent, in its conditions and purposes, can identify and cut the codes that guide its actions. This second level or logical class of still potential significations is called noise by Wilden. Unlike Shannon, Wilden considers noise not as an excluded third party, but as a mediation that is necessary to the production of significant information (along Henry Atlan's line of thought). ${ }^{1}$ Contained in this second great

${ }^{1}$ In the work that is considered to be the foundation of information theory, Claude Shannon (1948) designed a communication model in which he defined "noise": an event that may 
level, the logical class of information is where the agent performs, on the codes, the choices that will concretely guide its negentropic work (Figure 1).

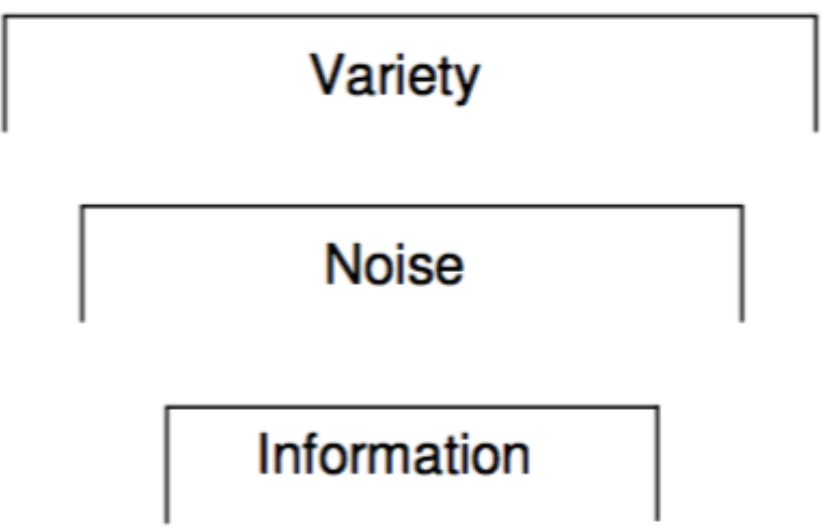

Figure 1: A logical typology of the information process (based on Wilden 2001)

\subsection{Organisation from Noise}

Living beings and, above all, human beings, have the inherent ability to adapt and change in response to environmental circumstances, as they are oriented by and may act upon the relation they establish between the informational differences and redundancies that they can capture and process. Atlan (1992), taking Heinz von Foerster as a starting point, developed the principle of organisation from "noise" based on this relation. The organism acts or reacts to different events in its environment (expected or unexpected) because its negentropy can only be sustained in a non-equilibrium stable state by its information-oriented actions in the environment.

Random events, therefore, can have negative or positive effects, depending on how they affect the agent. The meanings of this ambiguity depend on the position and purposes of the agent in the system. Under certain conditions, random events are essential for the negentropy of the agent. Under others, they will just barely be tolerated. Under still others, they will have to be controlled, corrected and even repressed. In any case, once processed, these events will have broadened the agents' memory or knowledge about the environment in which they act, and their own resources for action. The unexpected event, the 'noise', will then have contributed to improve organisation. That is why, in the case of a factory or any other economic and productive organisation, an 'error', 'failure', or 'defect', whether mechanical or human, ends up contributing to improve the organisation as a whole through changes in routines, improvements in maintenance or training, some alteration in the project (if applicable) and, always, adding experience and knowledge for workers, technicians, engineers and other working instances.

This process of improvement by an organism or system due to random events can go on for a variable amount of time, up to a limit that is mainly determined by its own conditions and structural possibilities. From that point of maximum growth, all the information available in this system and in its relations with the environment or with

intervene negatively - that is, contradictorily - in the quality of the message sent by a "sender" to a "receiver". Critics of this approach argued that the "noise" would be just another event that was typical of the set of systemic relations in which the "source" and the "receiver" were immersed. 
other systems is revealed. Consequently the effects of the Second Law will start to be felt more strongly and the system will enter an irreversible process of ageing and death. A large set of functional and structural conditions, varying from organism type to organism type, from environment to environment, from system to system, or from company to company describe different evolution curves over time (Figure 2).
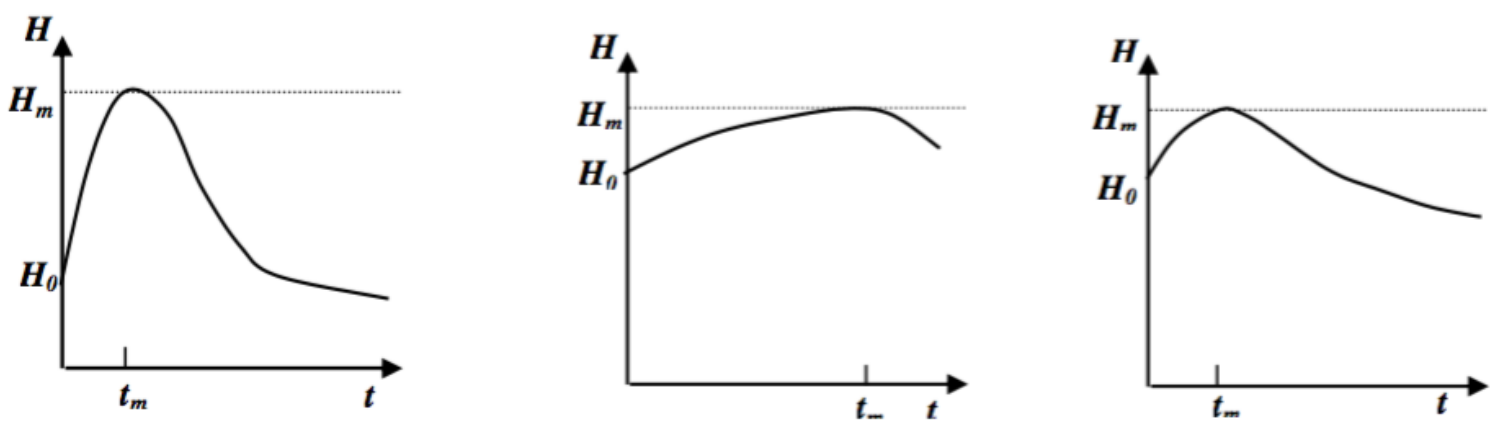

Figure 2: Some possible evolutionary curves of different organisms (based on Atlan 1992)

So, for example, in nature, the genetic code of an animal species would consist in some original (structural) redundancy that would define the possibilities of birth, growth, learning, survival, ageing and, finally, death for any individual of that species. During its lifetime, the organism has countless opportunities to act negentropically along the curve $H_{t}$ in Figure 2. Each action, especially in the growth phase, incorporates physical, motor, perceptive and other resources. These make the negentropic efficiency of the next action even more efficient. In other words, the organism experiences physical and memory growth up to a point beyond which its basic structure will allow it to do nothing more than keep a relentless and unsuccessful fight against ageing and death. The upward curve is replaced by a downward curve: which is to say, its maximum negentropy will eventually give way to universal entropy.

In this process, the organism gains information by registering redundancies in its nervous and muscular systems, and then, through memory, reducing those redundancies as it resorts to them at each new negentropic action. Memory contains senses or 'signifieds', incorporated into the code under the conditions and circumstances of each action. These signifieds enrich and, perhaps, slowly modify the code. In any living being, even if the memory of the species is genetically transmitted and capable of improvement in a biologically selective process, the direct memory of an individual is lost with the death of that individual. Only the human species, thanks mainly to articulated language, developed this particular ability to transmit individual memories to contemporaries and descendants. In human species and in the work performed by human beings, memory acquires, therefore, the form of knowledge: social, historical and cultural heritage for each and every one of us. Knowledge results from the interaction between individuals with their personal and social past, and also with their projects for the future.

Knowledge is a product of information, therefore a product of work. It also incorporates past work, for it is still redundancy that information reprocesses, enriches, and vivifies into new knowledge. Human knowledge necessarily incorporates constitutive human aspects, such as dreams for the future, emotion and drive, and cultural determinations. If information, in general, processes signals, 
human information, since it is oriented by knowledge, processes signs. And human informational work will be by nature semiotic work, involving an immeasurable range of connotative and pragmatic possibilities. As Umberto Eco says, "producing signs implies work, whether these signs are words or commodities" (1981, 170; translated).

\subsection{Information Value}

Along its evolutionary curve, any living organisation permanently relates the unexpected to the known, the random to the redundant. Redundancy converts preidentified messages into messages whose only utility is to immediately point out routes for the pursuit of what is new. When redundancy doesn't give this orientation, action tends to stop, but the spontaneous consumption of negentropy is not detained: or it may proceed even though the non-spontaneous consumption of negentropy continues. For example, in a factory, if a worker needs to watch a working machine for hours, paying attention to its clocks, gauges, and the noises it emits (which only the experienced worker knows well), he does so solely to capture random events (errors, unexpected and undesirable behaviour changes), not predictable ones. Redundancy is only useful because it can point to some original information, if it occurs. Therefore, it allows the worker to focus on the search for meaning to events whose origins or causes he initially ignores. That search will be semiotic work: a process in which senses, nerves and muscles, but, above all, the mind, are used in the association of signifiers to signifieds, given a context and its codes (Dantas 2001; 2007). That is why, recovering some of Marx's key categories, the value of "concrete living labour" will express itself in those moments in which the machine work reveals or produces a random event; not when it operates 'flawlessly'.

Negentropic work permanently moves within this dialectic between novelty and redundancy. It is activated by the different, new, original event. The more meanings or signifieds it extracts from an original event, in the shortest amount of time, the higher its efficiency. It is possible, both in the natural world and in the human social world, that novelty doesn't reveal its meaning easily, considering the agent's objectives. In such cases, the effort of searching and processing will become timeconsuming and tiring; uncertainty will grow, and this can, in extremes, lead to disaster. ${ }^{2}$ However, in most cases, memory, knowledge and experience quickly help to identify and correct the causes of a problem.

Assigning semiotic signifieds to the original event implies reducing ignorance or processing uncertainties in relation to the environment, or parts of the environment (Atlan 1992). By definition, this is negentropic work of uncertain or random nature. Once all the possible signifieds of the event are extracted, the resulting action, whose objectives and purposes are now already given, will mainly imply entropic consumption of matter and energy. However, this work expenditure will still be necessary to achieve the negentropic purpose of the organism, which it can hardly evade. This expenditure will have, in general, the form of some communication: in any productive environment, the worker or employee communicates the problem to their boss or, depending on the case, communicates directly with the machine they work with, aiming to correct it through control instruments. Every time this is done

\footnotetext{
${ }^{2}$ For example, consider air disasters. Nowadays, most of the time a disaster derives from a totally unexpected situation, whether through the training of the pilots or the onboard computers, so the pilots have no time to identify the origin and dimension of an anomaly. It is a case of $R_{\rightarrow 0}$, in which the negentropic efficiency of the pilots' efforts to find a solution will eventually result to be, tragically, equal to zero.
} 
they move muscles, nerves and neurons (Dantas 2001; 2007).

In the natural world, any living organism communicates its 'intentions' to other living organisms, originating persecutions, escapes, and so on. Any communication originates from a difference (information), but materialises in redundancy. As Bateson says, "the raison d'être of communication is the creation of redundancy" $(1987,133)$. Therefore, once the signified of a new event is obtained, random work is necessarily followed by redundant work. They are two moments of the same process: two moments that can either occur imperceptibly or indifferently for the agent, or in a way that is clearly perceptible or distinguishable by the agent. When I think and immediately type my thoughts onto a computer keyboard, I perform random and redundant work almost simultaneously. In an industrial organisation, if a worker spends hours watching the machine work without the need to intervene because everything is happening 'normally', they perform redundant work, until some unexpected event also calls for their semiotic competence to perform random work: identifying the problem, modifying commands on the machine, communicating the difficulty to other instances, and so on.

Since the resolution of a problem or the processing of random information enables any organisation (whether an individual or a capitalist company) to move forward along the $H_{t}$ curves in Figure 2, each point of these curves will express that moment in which the meanings or signifieds that could be extracted from information will already have been extracted, giving rise to the redundant work of communicating them through pertinent means. Therefore, any point in curve $H_{t}$ has to correspond to an originality curve that expresses a new event perceived at that point, and its growing repetition over time, as formulated by Moles (1978). We suggest that informational work is performed in the vicinity of point $O$, on the curve $H_{t}$ (Figure 3). There will be a degree of uncertainty beyond which the processing of information doesn't offer the agent any orientation ${ }^{3}$, and there will be a degree of redundancy beyond which time starts to become highly entropic, as it consumes the negentropy

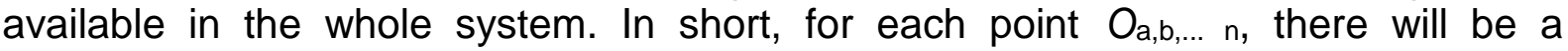

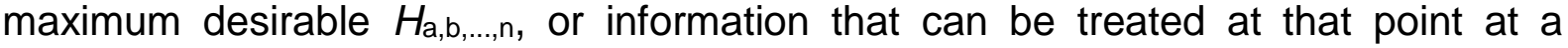
processing time that has to be a minimum value of $t_{a, b}, \ldots, n$. Thus, any $t_{a^{\prime}, b^{\prime}, \ldots, n^{\prime}}>t_{a, b}, \ldots, n$ will tend to be redundant in the face of the action already performed. This relation, as we suggest, will attribute a value to information relative to the agents in interaction with the environment (Dantas 1996; 1999; 2001).

${ }^{3}$ See Footnote 2, above. 


\section{Uncertainty}

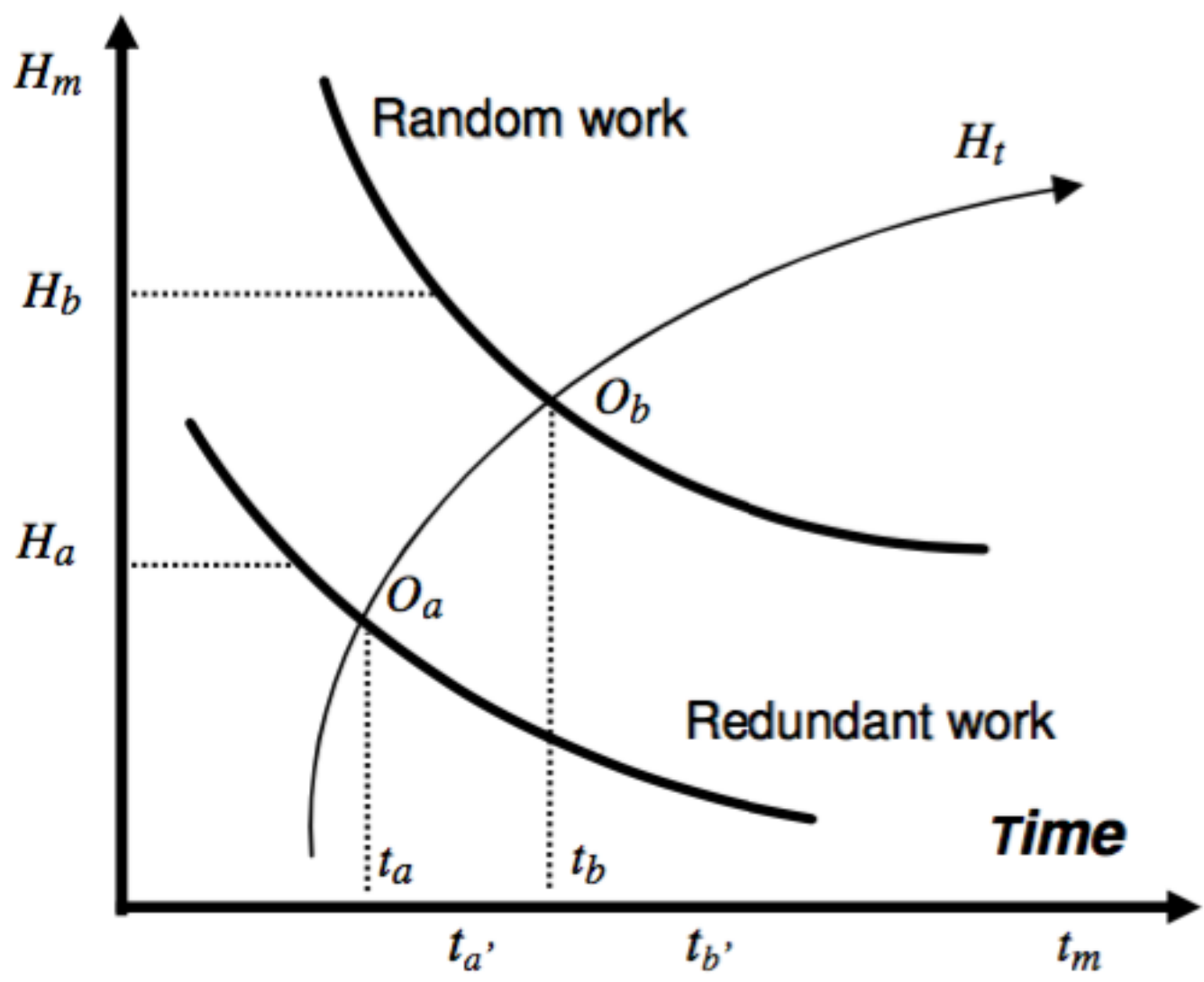

Figure 3: The value of information work

\subsection{Some Epistemological and Theoretical Comments}

Abraham Moles wrote that the "growing awareness of the material nature of information is very recent" and has developed thanks to information theory (1978, 271 ; translated). Until recently, the ideal aspects of the interpersonal relation seemed to be so evident that nobody was able to realise the material side of information. Moles adds that for Plato, Bacon or Spinoza, "the material aspect of the writing was no more than an ancillary contingency of which we must free the thought" (Ibid.).

We can go beyond Moles: we can say that this idealistic way to think about information started to change after Saussure's (1969/1916) definition of the sign as a dual unity of mind concept (signified) with its material support (significant) and Peirce's (1977/1931-1934) definition of the sign itself as a triad unit of its material qualities (qualisign and sinsign) and the rules that relate them (legisign).

All human relations are expressed and carried out by signs produced by the human body in action: affection, love, hate, taste, desire, dreams, projects, victory, defeat, etc.; matter expresses all human relations. It is the transformation of matter sound and light frequencies, chemical molecules - through which we can talk, listen, draw and see images, smell and so on. From an information theory perspective as well as from a Marxian point of view, there is no "immaterial work" or "immaterial economy". People who use these odd categories, as Gorz (2003), seem to go back to that old idealistic pre-Marxian way of thinking.

Another widespread misunderstanding about information and semiotic work is summarised by Manuel Castells in a mere footnote in the prologue of his extensive trilogy about the "information society" (Castells 1998). He agrees that he had to 
define "information" and also "knowledge" but, despite information theory, he didn't see any reason to "improve" the arbitrary and operational definitions by Daniel Bell and Marc Porat: "information is data that is being organized and communicated". This positivist definition that turns information into a thing ("data") is simply tailored to reduce it to a commodity. But as mentioned above, even Kenneth Arrow realises that the commodification of information is hard to achieve.

"Information is not property but form of the movement of matter", the Brazilian Marxist philosopher Alvaro Vieira Pinto wrote in his posthumously published opus magnum (2005, 379; translated). Heinz von Foerster also argues:

Since we think we know what information is, we believe we can compress it, process it, chop it up. We believe information can even be stored and then, later on, retrieved: witness the library, which is commonly regarded as an information storage and retrieval system. In this, however, we are mistaken. A library may store books, microfiches, documents, films, slides and catalogues, but it cannot store information. One can turn a library upside down: no information will come out. The only way one can obtain information from the library is to look at those books, microfiches, documents, slides, etc. One might as well speak of a garage as a storage and retrieval system for transportation. In both instances a potential vehicle (for transportation or for information) is confused with the thing it does only when someone makes it do it. Someone has to do it. It does not do anything (von Foerster 1980, 19; emphasis in original).

We can say the same nowadays about electronically stored data. In short: the relation between information and work is symbiotic. There is no living work without information, or information outside living work - outside the agent in action. Information is not a "thing", it is movement. It is not an "entity", it is a relation.

\section{From Industrial Capital to Information-Capital}

The exposition done so far will allow us to shed new light on the relation between use value and exchange value in Marx's theory. In a passage of Capital, Marx affirms:

A machine which does not serve the purposes of labour, is useless. In addition, it falls prey to the destructive influence of natural forces. Iron rusts and wood rots. Yarn with which we neither weave nor knit, is cotton wasted. Living labour must seize upon these things and rouse them from their death-sleep, change them from mere possible use-values into real and effective ones. Bathed in the fire of labour, appropriated as part and parcel of labour's organism, and, as it were, made alive for the performance of their functions in the process, they are in truth consumed, but consumed with a purpose, as elementary constituents of new use-values, of new products, ever ready as means of subsistence for 
individual consumption, or as means of production for some new labour-process. If then, on the one hand, finished products are not only results, but also necessary conditions, of the labour-process, on the other hand, their assumption into that process, their contact with living labour, is the sole means by which they can be made to retain their character of use-values, and be utilized (Marx 1996/1867, 130; my emphasis).

After all our previous exposition, it is hard not to admit that in this passage we can perceive that same relation between information and negentropy described by the fields of contemporary physics and biology. Machines and materials are preserved work (Marx also says "past labour" or "dead labour") that tend towards entropic degradation. But they can recover their previous capacity of providing work to a certain extent (even if it is modified; and because it is modified), thanks to the information introduced into them by an external agent: living work or labour. The utility of this work or labour - its use value - resides precisely within this competence, or knowledge, to give form to (or, to in-form) the "dead work" (physicochemical entropic work): to give it new shapes needed for its social utility. ${ }^{4}$

There is no commodity without the utility that is preserved or added by, as Marx writes, the:

[...] subjective factor of the labour-process, with labourpower in action. While the labourer, by virtue of his labour being of a specialised kind that has a special object, preserves and transfers to the product the value of the

\footnotetext{
${ }^{4}$ A fairly famous footnote introduced by Engels in the first chapter of Marx's Capital stresses the distinction made in the English language between the word work, related to the production of qualitative use values, and labour, which creates value and is considered quantitatively. But according to the British language dictionaries, work, as a verb or a noun, covers a wide range of signifieds, including "spent time and effort doing a task that needs to be done", "things you are paid or required to do in your job", and so on. Whereas labour can signify very hard work, usually physical work and work done by factory or peasant workers. Work is also the word used to mean physicochemical transformations in the inorganic world. To Robert Heilbroner, "the essence of work is that [its] tasks are carried out in a condition of subordination imposed by the right of some members of society to refuse access to vital resources to others" $(1988,85)$. In other words: work is an activity performed under the conditions of private property. Heilbroner wrote that "the term labor [was] decisively redefined" by Marx, for whom "labor creates objects not for their immediate enjoyment but as 'commodities', objects produced in order to realize their exchangeability for money" (Ibid., 120). Thus, labour could be any work carried out to produce commodities or exchange values. Another American economist, John K. Galbraith, seems to agree with the dictionaries, or common sense usage: to him, ironically, one of the big "frauds" of our times is the use of the "same word 'work' which signifies drudgery and boredom for lowpaid workers but enjoyment and reward for the affluent workers" (Galbraith 2004, 19-20). We can note that among the main European languages this is an issue only in English. In German, Marx's original language, the term is Arbeit. In the Romance languages, they say trabalho (Portuguese), trabajo (Spanish), travail (French), regardless of whether production is enjoyable or boring. In this article, the word labour is used to express only redundant factory or office tasks and jobs, which are usually repetitive, tiring and boring. Work is used for human activities - generally under private property conditions - but mainly for those creative, usually enjoyable, relatively free and often well-paid random tasks.
} 
means of production, he at the same time, by the mere act of working, creates each instant an additional or new value [...] This value is the surplus, of the total value of the product, over the portion of its value that is due to the means of production. It is the only original bit of value formed during this process, the only portion of the value of the product created by this process. Of course, we do not forget that this new value only replaces the money advanced by the capitalist in the purchase of the labourpower, and spent by the labourer on the necessaries of life (Marx 1996/1867, 146; my emphasis)

In short, in our terms, information (semiotically processed by useful living work) adds new value to past "dead" work. This increase of value doesn't derive from any "capitalist exploitation": it is intrinsic to the relation between useful work and its object. Any medieval artisan, for example, would have increased value when he transformed raw materials into new useful objects serving his customer. The function of capital is to expand this capacity of living work to the most, in all possible dimensions, in order to add a new value (on the condition of new utility) to the products of past work. Thus work, under capital conditions, adds surplus value to the products, now commodities. However, whatever the dimensions and practices of exploitation of work by capital, in every minute or every second of the work process, value is being added to past work, due to the transformations it goes through under the useful 'subjective' action of living work.

The value that concrete living work adds to materials and means of work submitted to its action is the information it processes and incorporates into them. This is the real essence of "useful labour" (in Marx's terms), this "natural gift" of the worker (and of every human being) that, among other things, allows capital to obtain "surplus value" from materials that otherwise would tend entropically towards wear and dissolution. The use value of the workforce does not consist in its eventual capacity of transforming and employing energy in the work process, but in its capacity of capturing, organising, registering and communicating semiotic information in it. Hence, concrete or useful work, having informational nature, will have value depending on the degrees of randomness and redundancy that it processes and communicates at a given time, along productive activities.

\subsection{Abstract Labour and Negentropy of the Worker}

As we know, the measure of the value of commodities won't initially be a function of processed, registered and communicated information, but of the (social) time of equal, or abstract, or simple labour, socially incorporated into it. If we abstract the useful nature of work, "all labour is, speaking physiologically, an expenditure of human labour-power" (Marx 1996/1867, 33), expenditure that can be understood as dissipation of the worker's negentropy as he or she informs and gets informed in the environment (or in the workplace). The need to recover this specific negentropy through the means of subsistence acquired by the salary will provide the measure of the value of the workforce itself. From the point of view of classic political economy, that value (which corresponds to the increasing entropy of the labour organism along the working shift) will serve as an equalisation measure for exchanges.

We can't ignore that, if the value of commodities (including the workforce) can be equalised by the subsistence value of the workforce, the surplus value and the profit - for they are obtained from extra working time beyond what would be physiologically 
necessary - are based on the basic non-equilibrium between the negentropy given by the information that is processed and communicated by the worker and the entropy of his body while he is providing labour. They are "two entirely different magnitudes", Marx wrote $(1996 / 1867,135)$. One is measured by $\Delta N$, the other is measured by $\Delta S$. Thus, capital is presented to us as a system far from equilibrium a "dissipative structure", as Prigogine and Stengers (1988) would say - that will keep itself in this condition as long as it can feed on negative entropy up to the limit of the restrictions imposed by natural resources and, no less importantly, on the possibilities of continuing to have living (creative) work in sufficient qualitative and quantitative dimensions to sustain the production and consumption of its increasingly elevated negentropic requirements. Marx was a pioneer in describing a system far from equilibrium at a time of the absolute predominance of the equilibrium and reversibility paradigms of Newtonian Physics.

Marx does not once ignore the close relation between the qualitative value and quantitative value of commodities and workforce. But during his time he could consider that the knowledge, abilities, and skills of the workers, and even scientific knowledge widespread through society, had no cost to capital. He notes in many passages of Capital that these elements comprise a "gift of Nature" of the workforce that, fortunately, the capitalist could acquire in exchange for the mere cost of the worker's subsistence. At that time, industrial productive processes were performed empirically, almost exclusively in workshops that employed workforce with relatively high degrees of knowledge, including mathematics, about production processes and techniques (Landes 1994; Hobsbawm 1997; Samuel 1992): the capitalist bought (as he has always bought) this knowledge (the qualitative use value of the workforce), while paying only the cost of its negentropic recovery (the quantitative measure of the value). Capitalism has always been cognitive.

The capitalist organisation of the productive process aimed, as Marx understood, to absorb the knowledge contained in human work: but it couldn't do so without employing and providing for the worker's body, holder of its memory and mind, reduced to labour. To take hold of the knowledge of work as labour, capital:

i) imposes that the worker's body should keep working as long as possible (for instance, by instituting working shifts of 10 hours, 12 hours, or more);

ii) reduces its replacement costs by lowering the price of essential goods or increasing productivity;

or iii) absorbs innovations born from the work process and generated by the workers themselves, innovations that increment the efficiency of labour by time unit.

Marx called the first dimension of surplus value absolute surplus value. He put together the other two under the same label of relative surplus value. But a careful reading, especially of Chapter XV of Capital Volume 1, shows that Marx made a clear qualitative distinction between these two dimensions of surplus value. The third dimension can be named intensified surplus value.

These three dimensions of surplus value seem to act in a contradictory way upon one another. The barrier to the endless expansion of capitalism, or the source of its crises and impasses, resides in its permanent need to employ the body of the worker in the process of informing matter - this constitutes its structural redundancy that, once destroyed, would ensure its collapse.

Due to the evolution of capitalism, its new technological production patterns, and to the struggles of workers and the conquests of democracy and welfare state, the upwards variation of the absolute time of living labour in advanced capitalism, especially in its "Fordist" stage, is no longer a condition for extracting surplus labour: 
on the other hand, free time becomes necessary to consumption and extended reproduction. Likewise, lower costs are no longer imposed for basic livelihood items, which, in Marx's time, weren't much more than essential food items, basic clothing and basic accommodation with scarce furniture. The 'subsistence' of the average worker, in advanced welfare state capitalism, usually includes a mortgage for a house, a car, vacation trips with the family and all the electronic gadgets that capitalist industry is capable of inventing and producing. To acquire all that, salaries need to be situated above the minimum 'consumption' level. That is, two out of three dimensions of surplus value wouldn't affect, in normal conditions, the process of valorisation. They can be considered neutral constants.

The intensification of work efficiency per unit of time has become the determinant relation in the production of surplus value. The decisive factor was the so-called 'second industrial revolution' in the early 20th century. This was arguably about replicating work time, as the real estate industry does by building (vertically) tens of housing units in the same area of land. In advanced industrial production, in the same time unit, the scientific and technical social knowledge incorporated into work processes - and even for each individual worker - can be replicated thousands of times from the same initial model. So, the entropic time of the worker, individually and collectively, is detached from the time of the machine. But their use value, individually and collectively - or their negentropic time - is still essential to valorisation, not as time that adds labour, but the opposite, as time that saves labour. That is, use value is considered as a capacity to process semiotic information and produce knowledge that minimises the interruptions of production at redundant times, or gets ahead of them, if possible, through product and process innovations at random times (Dantas 2001; 2007).

Living work or labour - since the 'second industrial revolution' - transforms little or almost no matter directly. Most matter transformation is executed by machine systems; that is, by fixed capital. Living work or labour, seen in a collective and combined way, but also individually, deals with semiotic interactions with machines through panels, clocks, gauges, buttons, handles and also sensory organs. It captures and processes semiotic information, based on individual or social knowledge, on industrial collective codes and general goals of the company (Dantas 2001; 2007; Burawoy 1979; Dejours 1995; Duarte and Feitosa 1998; Lucas 1974; Naville 1963; Rasmussen 1986; Zarifian 1996). Its use value is not directly related to the matter being transformed, but to the significant codes of techno-science learned at the company, at formal and technical education, and in social life. Therefore its field of work is communication: with the machine, with the colleagues, with other instances of the company.

Especially after the second industrial revolution, as this broad field of communication work expanded vertically and horizontally, the work and labour process has split into two instances that barely existed in Marx's time: the 'office' and the shop floor. Articulated to factory transformation, but separated from it spatially and socially, we see the expansion of engineering, management, technical and scientific research, and so on. The 'adult worker' from Marx's time is replaced by the 'engineer'. And the factory worker takes the place of the 'helper', the 'child', the 'woman', in the execution of redundant tasks. Knowledge for production, especially formal, scientific knowledge, is displaced to a space that is still usually near the factory, but differs from it in many fundamental aspects: a new caste of wage workers arises. This new caste's salary and consumption patterns, and the hierarchical positions they may fulfil, not forgetting the strategic importance of their work for the 
capitalist firm, tends politically and ideologically to much more complacent positions towards capital than those that shop floor workers and other hierarchically inferior employees had been willing to accept. ${ }^{5}$ The economic and social division between random work and redundant labour inside capitalism gained socially empirical and politically evident existence from the early days of Fordism.

But it may be said that Marx had already perceived this development would be the historical evolution of capitalism, in the essence of its contradictions.

Since with the development of the real subsumption of labour under capital or the specifically capitalist mode of production it is not the individual worker but rather a socially combined labour capacity that is more and more the real executor of the labour process as a whole, and since the different labour capacities which cooperate together to form the productive machine as a whole contribute in very different ways to the direct process by which the commodity, or, more appropriate here, the product, is formed, one working more with his hands, another more with his brain, one as a manager, engineer, or technician, etc., another as an overlooker, the third directly as a manual worker, or even a mere assistant, more and more of the functions of labour capacity are included under the direct concept of productive labour, and their repositories under the concept of productive workers, workers directly exploited by capital and altogether subordinated to its valorisation and production process. If one considers the total worker constituting the workshop, his combined activity is directly realized materialiter in a total product which is at the same time a total quantity of commodities and in this connection it is a matter of complete indifference whether the function of the individual worker, who is only a constituent element of this total worker, stands close to direct manual labour or is far away from it. But then: The activity of this total labour capacity is its direct productive consumption by capital, i.e. it is capital's process of self-valorisation, the direct production of surplus value, and therefore - a point we shall develop further later on - the direct conversion of surplus value into capital (Marx 1864; emphasis in original).

Marx saw during his lifetime how "intellectual" tasks were being absorbed in the industrial process of production and reduced to labour in the form of the production of commodities or, more precisely, capital. But, of course, he couldn't see the actual

${ }^{5}$ In his classic work The White Collars (1951), C. Wright Mills provides an accurate cultural and ideological portrait of the American middle class in the 1940s-1960s. John K. Galbraith $(1967 ; 1992)$ writes about the "technostructure" and the "satisfied class" in much of his work. Some good insights and analysis about the cultural or ideological position of the professional middle class in advanced and consumerist capitalism can be found in Bell (1976), Flichy (1991), Noble (1979; 1984) and other authors, both Marxist and non-Marxist. 
path this development would take; namely, since the early stages of Fordism, the rise of a new caste of relatively well-paid workers, dedicated to creative and pleasant jobs. But as Marx clearly saw, these jobs produce capital directly. The next section shows how this development has progressed up to the present day.

\subsection{The Value of Time in Marx}

In the first section of Capital, Volume 2, Marx presents his well-known formula:

$$
M-C \ldots P \ldots C^{\prime}-M^{\prime}
$$

This formula tells us that the monetary form of capital $(\mathrm{M})$ is employed by the capitalist on the acquisition of commodities $(C)$ that are introduced in production $(P)$, from which they emerge transformed in new valued merchandise $\left(C^{\prime}\right)$ that will be sold and transformed into surplus money $\left(\mathrm{M}^{\prime}\right)$. This expanded money, however, will need to return to the capitalist's hands, not only to put the profit in his own pockets, but also to buy again the necessary commodities (including workforce) to restart the cycle and keep it moving $\left(\mathrm{M}^{\prime} \rightarrow \mathrm{M}\right)$. The suspension points before and after $\mathrm{P}$ indicate that, during production, circulation is "interrupted" (Marx 1997/1885). The whole process, going through all its "metamorphosis", is denominated "industrialcapital cycle" (Ibid., 29).

All the effort of capital has always been aimed at reducing the time it takes to carry out the total cycle. However, it subsequently faces several barriers, as Marx notes. On the production $(\mathrm{P})$ cycle, for example, material transformation will always require some amount of time, depending on the nature of the materials to be transformed and the available equipment and technologies. In transformation, every process is interrupted by this waiting time, longer or shorter, during which the worker, individually and collectively, has nothing to do but wait for nature to follow its course (supposing no 'noise' occurs). General scientific and technological work will do everything possible to reduce this time. The value of this general work (of scientists, engineers, technicians and also factory workers), which aims to solve the problems presented by the time barrier of production and compress that time to an irreducible minimum, is found precisely within the socially useful information it is able to process and communicate.

In circulation, capital faces the barriers of what Marx designated "spatial moments" and "temporal moments". In order to generate value, both commodities and money need to travel distances that, in Marx's time, could take months. Ignoring many other factors that can affect realisation (circumstantial crisis, wars, etc.), physical space will always constitute an inescapable barrier. Overcoming it has required, since the early days of modern capitalism, large investments in various means of transportation and communication.

This is why, as one can read in Capital Volume 2, the "transportation industry" responsible for commodity circulation - constitutes "a separate sphere of investment of productive capital". However, "its distinguishing feature is that it appears as a continuation of a process of production within the process of circulation and for the process of circulation" (Marx 1997/1885, 88). This transportation industry is presented to us as a subsector of the larger communication industry:

But there are certain independent branches of industry in which the product of the productive process is not a new material product, is not a commodity. Among these only 
the communication industry, whether engaged in transportation proper, of goods and passengers, or in the mere transmission of communications, letters, telegrams, etc., is economically important (Marx 1997/1885, 30; my emphasis)

The "communication industry" - though Marx deals almost exclusively with the transportation area - generates value because its 'useful effect' is to allow the consumption of the commodity, moving it from one place to another. This useful effect is the movement itself, and this effect is consumed in the act of performing it. Therefore, the capital cycle here obeys the following particular formula:

$$
\mathrm{M}-\mathrm{C} \ldots \mathrm{P}-\mathrm{M}^{\prime}
$$

The transportation company advances monetary capital $(\mathrm{M})$ to buy commodities $(\mathrm{C})$, to which it adds value ( $\mathrm{M}^{\prime}$ ) without producing a new commodity (that is, without the transformation P... $C^{\prime}$ ), apart from the act of moving them from where they are produced to where they will be consumed.

This last formula reveals another essential aspect to the discussion we are proposing: that it is not alien to Marx's theory that there is production of value (and accumulation) without production of a commodity, without material transformation. Value is always associated with utility, and this is not necessarily contained in the results of direct material transformation. The labour of moving materials or, as we will see further, any other work or labour that results in saving time, can also be a source of valorisation; therefore, productive work or labour, even if it isn't specifically factory labour.

The cycle of valorisation and accumulation is only complete after the commodity has reached its consumer and the money has returned to the hands of the producer. The useful effect - hence the value - of transportation increases with the decrease of circulation time. This time gets into contradiction with production time $(P)$ and, therefore, all the subsequent development of capitalism is determined not just by the need to increase the productivity and intensity of labour (living and dead), but also, in the same dimensions, by this other need to accelerate circulation, thus decreasing movement times for commodities and money. Therefore, notes Marx, synthesising these dynamics in a phrase: the more widely capital expands around the world, the more it will need "to annihilate this space with time, i.e. to reduce to a minimum the time spent in motion from one place to another" $(1973,464)$.

Still in circulation, there is another time element whose equal interference in the valorisation of capital didn't escape Marx's perception: the time spent negotiating and administrating, which, at that point in history, directly consumed the labour of the capitalist in person. Marx designated this time as "temporal moments" of circulation:

Suppose the act of making the transition from commodity to money is fixed by contract, then this still requires time calculating, weighing, measuring. The abbreviation of this moment is likewise development of productive force. However, this is time still conceived only as an external condition for the transition from the state of money into that of commodity; the transition itself is presupposed; the question is the time which elapses during this presupposed act. This belongs to the cost of production. 
Quite different is the time which generally passes before the commodity makes its transition into money; or the time during which it remains a commodity, only a potential but not a real value. This is pure loss. (Marx 1973, 459)

"Calculating, weighing, measuring" - this is obviously not material transformation labour. Nor is its 'useful effect' movement from a place to another in space. We can affirm that its 'useful effect' is information that, as for locomotion, will be value without being a commodity. In Marx, it is clear that this work-time fits in the concept of circulation and, therefore, the reduction of this time will also imply development of productive forces. It won't be unreasonable to admit, by analogy, that its general formula will be:

$$
M-C \ldots I-M^{\prime}
$$

This formula tells us that the investor acquires means of production ${ }^{6}$ and work or labour capacity (C), not to employ in some material transformation or movement (or they might do it just as an auxiliary), but to use in the activities of perceiving, processing, registering and communicating information, thus giving rise to valorisation $\left(\mathrm{M}^{\prime}\right)$. For this valorisation, material transformation or movement is secondary (though these always occur, because materials and human beings wear out). So, the possibilities which both living and dead means can offer to process uncertainty and communicate redundancy in the shortest time are essential.

\subsection{Informational Work}

Detached from immediate material transformation (due to more than secular mechanisation, automation and automatisation of productive processes), living labour such as Marx knew it has evolved, becoming increasingly a combined process of semiotic and informational mental work that articulates itself through its random and redundant moments. That is, on one hand, work is not individual, but collective, combined, interactive. Each worker, whether a scientist or a shop floor worker, is no more than a link in a total system that is not contained in the limits of the individual firm, but includes the set of capital units that contribute differently, sharing work with one another, to the total production of valuable knowledge and marketable use values. This is just as Marx had predicted in his unpublished (until the 1960s) papers.

This combined body, general social production ${ }^{7}$ constitutes an evolved stage of intensified surplus value production, where on the one hand living work is dedicated to activities such as research, investigation, study, analysis and decision-making in science, technology, financial management and other areas related to the development and evolution of products and processes. This is mainly random work. On the other hand, living work is also dedicated to activities such as supervision, control, observation, direction or corrections of 'dead' (entropic) work that will aim to materialise the work of removing uncertainties. These tasks are predominantly redundant, although necessary to carry out the fixation of redundant information on

6 These means of production could constitute, in current days, computers and other information technologies, telecommunication resources, all kinds of office supplies and equipment, the means to produce and record audiovisual spectacles and other fixed capital necessary to process and communicate information in its different social or cultural forms: $R \& D$, design and marketing, consulting on economics and other services, artists or cultural spectacles, also management and other office activities inside firms, and so on.

${ }^{7}$ By general social production, we understand the current historical stage (capitalist) in which the "general intellect" announced by Marx takes form. 
the appropriate material supports for its intended utility.

A worker (an artist, an athlete, an engineer, a teacher or a shop floor worker) may individually perform both random and redundant work. However, socially and economically, certain activities or certain investments are by nature more random, and others more redundant. Scientific research, the development of a brand, providing consultancy, or artistic performance are types of work with a high randomness rate. From them, a model, a prototype, a report, or an audio and video matrix - some unique piece - will be extracted and then, depending on the case, will be replicated to be distributed. The production of this mould - to call all of them by the same name - is a kind of work with a relatively high degree of uncertainty, work which is subject to trial and error, difficult to control over time. It's a creative activity par excellence, totally dependent on the abilities and competences of concrete useful work. The mould created by this work is the central pillar of reproduction of supports within the same time unity: be it in physicochemical industries reproducing a specific team design thousands of times, or in cultural industries recording a cast performance (Dantas 2001; 2007). Of course, for each industry, even for each piece, no matter the production process, there will be many different kinds of moulds, in shape, weight, materials and so on.

If the mould condenses in itself all information processed and all knowledge produced, the communication of this knowledge, especially its commercialisation, will require some particular means of transportation - a physicochemical support linking social and economic agents, capital units and, last but not least, consumers. Fixing the processed information on that support, or replicating the mould, may still require a good amount of redundant living labour. The intensified magnitude of this labour by product unit will usually depend on the materials and dimensions of the supports: they can be thousands of music CDs, or pairs of tennis shoes from a famous brand, or a single huge bulk carrier ship, or just a few units of a large commercial jet, or a gigantic hydroelectric dam. The more material they contain, the longer it takes for their stages of physical and chemical transformations, the more relatively redundant labour the communication will demand, such as typing, final designs, assembly of components or pieces, operating machines and equipment, or watching control panels. As with the other phenomena related to circulation and communication, as long as these movements are not concluded, the informational product will not be ready for use.

'Reducing time' - this time of redundant labour - has been a crucial issue for capital since at least the time of Taylor and Ford. For this purpose, capital has been investing in the development and use of several technologies in transporting material and communicating information, aiming to reduce material transformation time to be as short as possible. To achieve this, since the last decades of the twentieth century, capital has made use of modern digital technologies, not to mention all the technology that industrial capitalism was able to generate and improve since the first industrial revolution.

This is what led to the current accumulation regime that can't do without random living work (therefore, 'creative economy', 'cognitive capitalism' and other expressions that recognise the central role of highly qualified concrete work in the valorisation process). But, unlike in Fordist times, the current regime tends to no longer recognise any value in redundant living labour: it tries as much as possible to eliminate it by automation or (if not yet possible) to transfer it, thanks to worldwide telematic networks, to countries, cities, peripheral neighbourhoods, where it can be exploited in conditions that are similar to or worse than those that Marx witnessed in 
the first half of the 19th century. These tasks also integrate the "total labour capacity" (Marx 1864), but because they are carried out by over-exploited workers in peripheral 'sweat shops', some analysts - ignoring the real information working value of the total process - see in its particular and secondary segment a kind of capitalist return to earlier times of widespread absolute surplus value production. ${ }^{8}$ But capital is developing a new machine generation empowered by artificial intelligence (the 'Internet of things') and the extraordinary capacity to reproduce things (3D printing) that promise to finally replace the remaining demand for the kind of living labour that has very low semiotic competency. Political establishment leaders and organic intellectuals are saying that we are experiencing the beginning of the 'fourth industrial revolution'. Could this development bring about capital's old dream of accumulation without living labour?

Because of its intensive development of fixed capital discharging redundant living labour, capitalism, in its new informational phase, has become a mode of production that excludes a large contingent of the population from production processes and usufruct of wealth. This population segment is no longer even seen as the "industrial reserve army". The social and ethical consequences of this exclusion are present, visible to everyone.

\subsection{The Cycle of Productive Communication}

As the evolution of capitalism reduced circulation and turnover times and expanded the dimensions of semiotic informational work, it would end up resizing quantitatively and qualitatively, in general social production, the information valorisation cycle which, as we saw, was perceived but not elaborated on by Marx: at his time, exclusively semiotic work was carried out by the individual businessman and a few assistants, helped by paper and dip pen.

In the cycle:

${ }^{8}$ An example: in A Companion to Marx's Capital Volume II, Harvey $(2013,102)$ quotes a passage from Capital Volume III, in which Marx describes the relation between furniture manufactures and the merchants or owners of the stores where the furniture was sold. To Harvey, this relation is similar to today's relation between brand corporations like Nike or Benetton and peripheral "sweat shops" around the world. But there is a very important difference. The furniture manufactures at Marx's time were "run more or less like handcrafts by a single minor master and a few journeymen", as Marx described it. This means they were really cabinetmaker artisans that required a merchant to facilitate the distribution of the chairs, tables and bureaus they manufactured within a broad market. It was a similar relation to that between an artist, like a writer or a musician, and a publishing house. Without this relationship, pre-Internet, they were unable to distribute their work to hundreds of people. As shown above, quoting Samuel and other industrial historians, this was a common relation in the English industry in the 19th century. Today, knowledge in production is not empirical but basically scientific-technical, and it is the brand corporations that master it. These corporations' R\&D and engineering labs design their own products, specify moulds and materials very carefully, and establish the targets and time of turnover production. In Fordist times, these activities of manufacturing and assembling the products had to be carried out in one big factory close to the engineering labs, because this could reduce turnover time (Chandler 1977). Today, those factory activities are entrusted to external suppliers, due to technologies of communication and transportation that help reduce the turnover time even more with additional advantages (to capital) in reducing costs with redundant living labour. 


$$
\mathrm{M}-\mathrm{C} \ldots \mathrm{I}-\mathrm{M}^{\prime}
$$

Entropic ('dead') work and living work or labour will perform different functions, precisely because the goal is not to transform or move matter and turn it into a new use value. Basically, as we have shown above, the materials are there simply to be used as instruments and equipment by living work or labour.

Considering the investment of capital in information valorisation; that is, in the times of random and redundant processing, money (M) is advanced to recruit living work in the production of living activity (Boutang 2001) of collecting, processing, registering and communicating semiotic information (I). Hence, obtaining surplus money $\left(\mathrm{M}^{\prime}\right)$ will be a function of the processed relation randomness/redundancy, that is, of the value of information as discussed above in Section 1.2.:

$$
M-I-M^{\prime}
$$

On the other hand, since information can't be detached from a physicochemical communication support, capital, when ruling informational work, will need to assign entropic material work to it: instruments, equipment, machines or other materials, to generate and register the desired knowledge. Thus there will be a factory cycle of production, in which raw materials, machines and energy are acquired by an investor, to be consumed in the production of physicochemical supports for use in processing and communicating information. Our language has become accustomed to calling such values 'commodities':

$$
C-P-C^{\prime}
$$

The time of this cycle tends towards a minimum but it finds its lowest limit in the irreducible barriers of the physical and chemical conditions of the materials in transformation or movement. Particularly after the development of informatics and microelectronics, this cycle became automated to extreme levels, such that it must now function in a continuous cycle, dependent on living work or labour for supervision to ensure it is not interrupted.

In the information processing cycle, time tends to an acceptable maximum for random work on the axis of uncertainty; and to a minimum, if possible to the limit of zero, on the axis of redundant labour. In scientific research or technological development, error is presupposed during activity. In order to produce a movie scene, there are several rehearsals. Until you obtain the desired model of a garment or a vehicle, many designs and tests must be done. However, once you obtain the knowledge, the film or the final model of the product, all subsequent communication will widely use digital means and global computer networks. Because of these technologies, in the last two or three decades many stages of redundant labour and the huge Fordist-era amounts of workers could be eliminated, or made more "flexible", as Harvey (1996) suggests. This reduction results in a total cycle of productive communication, in which valorisation and accumulation are no longer derived from a sequential relation between the time of physicochemical work and that of informational labour, as they were in Marx's time, but from two temporal cycles that are distinct, though interrelated (Dantas 1999): 


$$
\begin{aligned}
& M-I-M^{\prime} \\
& C-P-C^{\prime}
\end{aligned}
$$

This rupture of the whole circulation cycle time was probably first perceived and studied by early researchers in the field of political economy of communication. Zallo (1988) calls it "no unit of work process" because the conception of an artist's work no matter if it is produced by an artist (e.g. a writer) or a collective (e.g. a movie cast) - is a separate procedure from its factory/physicochemical reproduction. Huet goes further:

In the current control state of the artistic use value production process, work is still insufficiently reducible to abstract labour [that] makes possible to submit its product change to the value law [...] In fact its use value is that of a unique product (Huet et al. 1988, 99).

This is the definition of any artistic product, even in the age of its technical reproducibility: uniqueness. The artistic use value is intrinsically linked to the performance and empathy of the artistic workers. Even if the product is recorded, its use value remains work in action: the artist's presentation and the action he produces in its readers, listeners, and viewers (emotions, desires, feelings and so on). Today, this model of work process, first developed in those typical cultural industries, has become dominant in all industries that are in the most advanced frontiers of presentday capitalist accumulation patterns. This is simply due to the fact that "aesthetic production is integrated to the general commodity production" as Jameson $(2006,30)$ states so effectively. The determinant capital valorisation process is supported by 'creative' work - work that is, as all artistic work, hardly reducible to abstract labour.

On the other hand, at the end stage of any industrial total process, the value of a piece of any physicochemical information support can be negligible. For example, the factory production of a CD can cost less than a dollar per disc. The manufacture of a pair of jeans from Benetton or Diesel can cost around 20 dollars. But in the shops, the CD will be sold for 17 dollars and the jeans for USD 300 dollars or more (Witt 2015; Lima 2005). How can this be explained? The industrial value of these physicochemical supports is very low per unit because of the very high amount of fixed capital in the entirety of its supply chain $\left(C-P-C^{\prime}\right)$ and the very low value of remaining redundant living labour in assembling or tailoring or packaging the final product unit. However, the final sale price of a product unit is so high because it has to cover the value of relative high cost of random living work, plus uncertainty time in R\&D and design, fixed capital investments, marketing costs and, last but not least, monopoly prices due to intellectual property. This last issue will be discussed in the next subsection.

Marx spoke of "industrial capital", the capitalism of his time, because the valorisation process was occurring mainly in the factory (Marx 1997/1885, 29). In that industrial capital cycle, advanced capital acquired commodities that would be transformed by the action of living labour into new commodities during the (sub)cycle of production. But in the present-day cycle of productive communication, living work 
or labour doesn't aim to transform any commodity. Living work or labour uses physicochemical supports (equipment, tools, facilities etc.) to process and communicate information. The use of these physicochemical supports can happen in creative, rich activities, like those performed by engineers or artists in their projects or performances; or in repetitive, poor activities, like those that require routine movements of merely joining pieces, carried out in many garment factories. Therefore, at any instance of work, the material used there arrives totally or almost totally transformed by entropic ('dead') work systems.

These entropic work systems are fixed capital in Marx's terms. Whether big machines, means of transportation, telecommunication cables and satellites, office computers, or the software and algorithms embedded in them, these are frozen redundant information that has been previously randomly processed and registered by living work in R\&D labs, engineering departments, design and marketing offices and so on. Therefore, $\mathrm{C}$ can develop into $\mathrm{C}^{\prime}$, not because it contains surplus labour (living, simple and material), but because of the information value embedded therein, suppressing many other turnover times of production, circulation and communication.

Capital cannot discharge itself from productive living work, the source at least of intensified surplus value. But as Marx said:

the more the metamorphoses of circulation of a certain capital are only ideal, i.e., the more the time of circulation is equal to zero, or approaches zero, the more does capital function, the more does its productivity and the self-expansion of its value increase (Marx 1997/1885, 73).

Because of this increase, capital is evolving to discharge its "ideal metamorphosis" from the physicochemical production of information supports. Nowadays, in the cycle of productive communication, circulation will not be necessarily 'interrupted' during production. The return of added money may occur without material production even happening, for example, in patent or brand licensing. Increasingly, the consumer first transfers money instantly from their account to the vendor's, through automatic debit or online shopping, then receives the commodity in a few seconds (if it is a product that is downloaded online), or in a few days if it's a physicochemical object that will be delivered by traditional post. In other words, the advanced capital can return to the investor before the complete circulation cycle of the physicochemical commodity is ended. The extraordinary capacity that capital has reached to value information exclusively through almost annulling the time of communication, thereby automating the times of circulation and turnover in relation to those of production, will be the base of "informationalisation" (Castells 1998) or "financialisation" of the economy (Chesnais 1996).

\subsection{Realisation and Appropriation of Value}

As a consequence of what was discussed in the first part of the present article, the value of an informational product for the person who acquires it - whether it is a software package, a music CD or a branded pair of tennis shoes - lies in the action this product will allow its buyer to perform. The nature of this action may be technical, professional, social, emotional, psychological: it doesn't matter. What interests us is that, during contact with the informational product, the agent will initially notice its originality-value, but soon, and often rapidly, will depreciate its physicochemical 
redundancy. This will not have any higher value than to redundantly replicate the content of concrete ("creative") work registered on them.

However, we have to distinguish two types of use value (or informational supports) in contemporary capitalism. Entropic use values are those whose main utility-attribute is to be consumed, that is, to be worn out over time or even totally destroyed after a while: food, for example. However beautiful, fragrant or tasty a food is, it only fulfils its utility if it is digested, because, in the end, its use value lies in its protein, vitamin and energetic attributes. Therefore, clothes, machines and even buildings need to be effectively used and then entropically depreciated to fulfil their use values.

The opposite happens to objects containing information of an artistic nature: audio discs, books, movies, etc. When you listen to a song on a disc, you are reproducing the sound. This reproduction can be executed endless times if you are careful and keep the disc in good condition. The use value here lies in the replication of the object, in the active relation that the agent establishes with the energy modulations that connect the musical support to his hearing system. This information's use value is negentropic. It will not necessarily be depreciated by time. Even now, for example, we can appreciate (and thus, publishing companies can continually re-edit) Homer's epic poems. In these cases the support doesn't matter: it may be parchment, paper, e-reader and so on.

Norbert Wiener and Kenneth Arrow understood exactly that it wouldn't be possible to negotiate negentropic goods as commodities. The whole of economic theory, classical and neoclassical, failed to consider this hypothesis and excluded it from its formulations. This is the main contradiction that information-capital needs to solve: since accumulation is now immediately extracted from information, how to appropriate a value that is not a commodity?

For information-capital, entropic and negentropic use values differ from each other by the random dimension of concrete work performed on them: 'creativity', 'style', 'design', 'beauty', and so on. This is the great difference between information-capital in our time and industrial capital in Marx's time. Formerly, knowledge for production was basically social, widespread among qualified workers. The products did not vary much between them, except mainly for the amounts of social time of abstract labour that each commodity could contain. Now, because products can differ so widely due to their aesthetic attributes designed by concrete random ('creative') work, use values have been emptied from that exchange measure. Capital, in order to accumulate and grow, started to impose upon society a new appropriation principle no longer based on exchange, but on informational rents extracted from monopolistic intellectual property rights over the use of brands, inventions, images, ideas and so on. This expresses, in political and legal terms, a new capitalist accumulation pattern in which "exchange value [must cease to be the measure] of use value", as Marx anticipated in the Grundrisse $(1973,625)$.

However, intellectual property rights by themselves are not enough to guarantee these rights. The volume of fixed capital and the time of redundant labour per product unit needed to fix the design on a support that is adequate for use will also have decisive roles in capturing informational rents. If these required levels of fixed capital and redundant labour are high, such as, for example, in the automotive industry, they establish barriers to entry that basically impede the emergence of competing companies who merely copy the designs (thereby lowering their costs to just those of employing redundant labour). But if the levels are very low, as, for example, in the fashion or music industry, replicating the moulds already created by random work and established in the market will not demand much investment from opportunistic 
entrepreneurs. Thus we can see the expansion of millions of micro-factories and micro-retailers all over the world, but mainly in the capitalist periphery. Labelled as 'pirates' and fought with the use of police forces, they struggle fiercely for survival against the monopolist owners of knowledge.

Just as the access conditions to land and other natural resources, when fenced or monopolised, can generate differential rents - discussed by Marx in Volume 3, Section 6, of Capital - in this stage of information-capital the access to 'invention' or 'creation' protected by intellectual property rights can also generate differentiated informational rents, depending on the barriers to entry they find in capital units or blocks that own these rights. These barriers can be 'natural'; that is, provided by nature in the process of producing use value; and institutional; that is, defined by the conditions the capitalist state - allied with interested corporations - displays in order to efficiently repress "pirate" practices (Dantas 2014). If those conditions are very weak or scarcely viable, as for the music industry in the 1990s, the replication cost of any informational piece literally tends to zero, annulling the income that can be extracted from the products of 'creative' living work.

The music industry, as with all content industries, had organised itself since its early days to reproduce and distribute its negentropic use values in the form of pseudo-commodities that, in order to be produced, demanded high investments in fixed capitals and working time: books, discs, copies of films. These barriers to entry have been taken down by the new Information and Communication Technologies (ICTs). These industries saw themselves facing a severe crisis, but they were reinvented by a solution proposed by the entrepreneur Steve Jobs: the iPod/iTunes system. The consumer doesn't need to buy records anymore. He or she just needs to buy a music player and download the songs from a virtual store, accessible only to those who have a password. Obviously, he or she will have to pay for each download. Business literature calls this business model "walled garden" (Marsden et al. 2006; Vianna 2011).

The model would expand quickly, though it had been evolving for a while before Jobs announced his 'invention'. Since the 1980s and 90s, corporations based on 'walled TV', only accessible upon subscription, had sprung up in the USA and Europe. Walled TV comprises associations of large film studios, owners of transmission infrastructure by cable, satellite and others, and already established media groups. The brand names of some of the biggest conglomerates denote this association: Comcast-NBC-Universal, Time-Warner, Disney (owner of ESPN, ABC and other channels) and so on. They offer paid access to a range of television entertainment organised according to the terms negotiated by producers, programmers and infrastructure owners. These infrastructure owners seek a large subscriber base. Consequently, they need programs and channels, that is, "content" that can attract that "audience".

Arsenault and Castells (2008) showed in a detailed study how the capital structure of media groups is entangled with financial capital. Fidelity Investments group, for example, holds $4.1 \%$ of Time-Warner capital and $5.5 \%$ of the capital of its competitor, Disney. Capital Research, another example, holds $8.3 \%$ of Google capital (while Fidelity has $11.5 \%$ ), and $11.6 \%$ of the capital of its competitor Yahoo!. AXA group holds $5.8 \%$ of Time-Warner, almost $3 \%$ of Disney and $3.9 \%$ of Apple, which has $6.4 \%$ held by Fidelity. These are not exceptions, they are the rule: the same few financial groups and banks are associated with several global media conglomerates. It is also common that the same people meet in the councils of more than one conglomerate, representing their shareholders. 


\section{The Society of the Spectacle}

It will be hard to understand the extraordinary political, economical and cultural power acquired by the media-financial capital in contemporary society if we don't discuss and investigate more deeply the society of the spectacle denounced by Guy Debord in the 1960s: the capital "to such a degree of accumulation that it becomes an image" (Debord 1977). The aestheticisation of commodities means that the attributes of use values, including the entropic ones, are mainly related to 'tastes', 'desires', 'affections', 'identities', 'distinction' and other subjective values, and less related to their possible instrumental functionalities. There will not be much subjective difference between 'consuming' a piece of clothing or a music CD, because we don't consume "things" but "trends", "lifestyles" (Fontenelle 2002). There may be some distinction in this kind of consumption in terms of identities such as age, gender, social or cultural groups, and so on, as discussed by Bourdieu (1979). Utility has become even more a function of "fancy" than of the "stomach". ${ }^{9}$ And, not least important, when the redundancy of informational use value is communicated, utility also has to express itself also in a time of accelerated, volatile, disposable consumption. Therefore, the so-called 'consumer' must naturalise a lifestyle that will keep them equally in permanent (consumption) activity and also make them move within time intervals tending to zero. Hence this "disposable world" we live in, as discussed (among others) by Fontenelle (2002) and Harvey (1996).

"Production, then, is also immediately consumption, consumption is also immediately production" (Marx 1973, 24). Of course, here Marx wasn't considering space or time: he was thinking about the dialectical relation between production and consumption. A cultural human group doesn't produce what won't be consumed due to its behaviours and beliefs, and, given its specific cultural codes and subcodes, doesn't consume what isn't produced by its real demands and necessities. Before being an economic determination, production and consumption are inextricably interrelated cultural determinations. That's why consumption itself also is productive, as Marx wrote in the Introduction which may be read in both A Critique of Political Economy and Grundrisse.

We can also say: "Emission is immediately reception, reception is immediately emission" (Dantas 1996, 61). Receiving a message is also immediately sending a message to the so-called "emitter" - and vice-versa (Bateson 1987; Bateson et al. 1981; Escarpit 1991; Bakhtin 2011; Volóshinov 2017).

This is why Smythe (1977) states that the "audience" works and its work participates in generating value in the cultural industries. Semiotic work is necessarily carried out, for example, by an 'artist' who interprets a scene or by the 'spectator' who interprets the audio-visual text on TV or cinema screens. The spectator is not 'passive'; on the contrary, they laugh, cry, applaud, agree, disagree, like, dislike, become happy or irritated. The work's value is in the mediation - the sign - produced in this living interaction: semiotic information.

If on one hand the capitalist evolution increased the average income, leisure time and aesthetic consuming needs of the worker, on the other hand - and because of this - it also converted this leisure time into productive time, that is, time spent in the valorisation of capital. Part of this time began to be consumed in activities in which

9 "A commodity is, in the first place, an object outside us, a thing that by its properties satisfies human wants of some sort or another. The nature of such wants - whether, for instance, they spring from the stomach or from fancy - makes no difference" (Marx 1867, 27). 
formerly the capital had to employ and pay for redundant living labour: activities such as bank automation and other 'self-services', where the consumer has started to perform functions that used to be carried out by a specialised worker. Due to bank automation, the client, in an immediate semiotic relation with the 'dead labour' of ATMs, has started to work for the bank - without receiving any recompense.

The leadership in this process of making every minute of every person productive was naturally taken by the media and its associated financial capital. Their recently evolved socio-digital networks, commonly known as 'social networks', are platforms built over physical and logical telecommunication and computer infrastructures, through which billions of people all over the world, regardless of time and space, can build social relation networks. The service is often offered for free. Corporations are paid by advertising revenue, just like the 'old' television was and still is. However, unlike 'old' television, social-digital networks enable the 'audience' itself to produce content to attract more 'audience', in a recursive process: content attracts audience that produces content that attracts audiences, and so on. The cost of work to produce this content is substantially reduced to the limit of zero in this business model (Evangelista 2007; Dantas 2011; Scholz 2013).

Google, Apple, Microsoft, Samsung, Facebook, Amazon, and many others are offering individuals to perform their routine, day-to-day, familiar or even professional activities online, providing them material supports to act. For the corporations, these supports wouldn't generate value if people weren't permanently, every minute, sending and receiving signs through them and performing some kind of informational semiotic work with them. These platforms are produced, sold and generate large profits for the electronic industry supporting the associated media and financial capital, because they present a use value that is action: the activity they provide the users, who are all incorporated to the cycle $\mathrm{M}-\mathrm{I}-\mathrm{M}$ ' as semiotic living work.

Socio-digital networks provide the individual - already a fully integrated, subsumed participant in the capitalist society of the spectacle - a large free space for direct participation inside the spectacle itself, perhaps searching for fame, even if it is instant and volatile in a society where success (for products, songs, people) must be fast and disposable. The individual participating in this way within socio-technical networks says, "I am the show" (Sibilia 2008). Each one, searching for success - for example, with friends and family, by the number of 'likes' on their pet cat photo presents what they really are: "little disposable spectacles, some ingenious entertainment with no further ambitions, or even a celebration of the most vulgar stupidity" (Ibid., 308).

The work and valorisation processes on the Internet and socio-digital networks also allow the redistribution of work in terms of space and time. This redistribution applies at least to artistic, scientific and creative work, which can keep their essential social and cooperative conditions, but no longer need to be concentrated the same location. Procter \& Gamble offered, on the Internet, $\$ 300,000$ to any chemist, anywhere in the world, who could provide a solution to remove wine stains from clothes. Obviously, in this situation the intellectual property over that knowledge belongs to the company. On the course of this action, the jobs of most of their seven thousand chemists would have been seriously threatened. Goldcorp, a mining company, surprisingly shared online their geological maps. They paid half a million dollars to the geologist who, having studied the maps, pointed out the location of a mine where further studies revealed a deposit worth $\$ 3.4$ billion. The market value of Goldcorp soared from $\$ 90$ million to $\$ 10$ billion (Tapscott and Williams 2006). 
This form of socially combined work is expanding to all areas of society, from the yuppies with their 'notebooks' in the cafeterias to subway trains where factory and office workers distract themselves with mobile phones while commuting. This kind of work gathers the general social knowledge - general intellect, according to Marx but still in a subordinated (to private property) and alienated way that Marx couldn't have imagined. This form of work has become an essential primary resource for continuous capitalist development. The Internet has emerged as a powerful tool for direct and immediate connection with all individuals with access to it. From the web emerge not only solutions 'on demand', as promoted by Procter \& Gamble or Goldcorp, but also many random solutions, blogs and videos that become suddenly and surprisingly successful, attract millions of 'likes' and followers and, therefore, publicity money for the owners of the network (and even some income for the authors), all at relatively low cost and high profitability for financial capital.

\section{Conclusion}

Information-capital can be summarised in the logic typology shown in Figure 4: the concrete living work of billions of individuals connected by computers, mobile phones, debit/credit card reading machines, and so on, constitutes the variety to be captured, processed, registered, and in-formed - that is, given a form that produces profit and accumulation - by spectacular financial capital.

\section{Connected population}

\section{High skilled employees, artists etc.}

\section{Financial capital}

Figure 4: A logical typology of information-capital

This relation is mediated by the living work of scientists, engineers and other highskilled technicians that create algorithms of the socio-digital networks and other automatic systems for treating, communicating and registering information (ICTs) that are spread around our social life. The same occurs with artists, soccer players and other athletes, popular musicians, 'showbiz' celebrities, and new Internet celebrities that give form, or orientation, to the attention of that otherwise scattered population, mobilising its work as 'audience' to valorise media-financial, or spectacular, capital.

For financial capital, the spectacle has become the mode of existence of informational semiotic work, posed as its limit source of generation and extraction of value. Yes, work is still the source of value. However, it is emptied from its entropic measure of value. The value of information takes effect in sharing, in the interaction, in communication. If the value of measurable abstract labour tends to zero, the measure of the commodity value tends to be null. Capital has lost its value measure, 
as Jappe (2003) and Prado (2005) also concluded. If the Law of Value that Marx described for 19th-century industrial capital has been overcome, then capital has nonetheless been displaying an unexpected capacity to survive due to the extraordinarily intensified surplus value generated in its new informational-capitalist stage. This dimension of surplus value can be appropriated mainly with the help of enclosures generated by intellectual property laws that create 'walled gardens' and other monopolist capital accumulation models. Because of this, capital seems to be still growing, even though it is sustained on an increasingly critically narrow social and economic base.

Capital has evolved into the current stage of rentier capitalism. Communication technologies that annul temporal distances to nanoseconds have sustained this development, as well as the high speed of circulation and the high turnover times that characterise it. In respect to the physical-chemical world, Prigogine and Stengers (1988, 65; translated) wrote that "the more efficient the communication is inside a system, the bigger will be the proportion of insignificant fluctuations, incapable of changing it". Likewise, in the social world of capital, could the extraordinary efficiency attained by its means of communication have already taken capitalism to the verge of reaching its negentropic limits of transformation and growth?

It is possible that the current crisis is not just one more historical crisis of a Kondratiev wave, but an actual civilisation crisis. Seeing the increasing fragmentation, social chaos and the ecological crisis that surrounds us, it becomes evident that we are reaching certain limits. In fact, this is not an original statement. Robert Kurz (1993) was one of the first to say this almost 30 years ago. Benjamin Barber (1995) also wrote something similar. If they are right, then this means capital is being exploded by a new global barbarian order sustained by humans who have been excluded or discharged from the capitalist conditions of production and the consumption of wealth. Surely this is not the future Marx dreamed of. Neither is it our dream of the future.

\section{References}

Arrow, Kenneth J. 1977/1962. Economic Welfare and the Allocation of Resources for Invention. In The Rate and Direction of Inventive Activity: Economic and Social Factors, edited by the National Bureau Committee for Economic Research: 609-626. Princeton, $\mathrm{NJ}$ : Princeton University Press.

Arsenault, Amelia H. and Manuel Castells. 2008. The Structure and Dynamics of Global Multi-Media Business Networks. International Journal of Communication 2 (1): 707-748. Accessed 8 August 2017. http://ijoc.org/ojs/index.php/ijoc/article/ view/298/189

Atlan, Henri. 1992/1979. Entre o Cristal e a Fumaça. Rio de Janeiro, RJ: Jorge Zahar Editores.

Bakhtin, Mikhail. 2011/1979. Estética da Criação Verbal. São Paulo: Martins Fontes.

Barber, Benjamin R. 1995. Jihad Vs McWorld: How Globalism and Tribalism Are Reshaping the World. New York: Crown.

Bateson, Gregory. 1987/1972. Steps to an Ecology of Mind, Northvale: Jason Aronson.

Bateson, Gregory, Ray Birdwhistell, Erving Goffman, Edward T. Hall, Don Jackson, Albert Scheflen, Stuart Sigman and Paul Watzlawick. 1981. La Nouvelle Communication. Paris: Éditons du Seuil.

Bell, Daniel. 1976. The Coming of Post-Industrial Society. New York: Basic Books.

Bourdieu, Pierre. 1979. La Distinction: Critique Sociale du Jugement. Paris: Les Editions de Minuit. 
Boutang, Yann Moulier. 2001. La Troisième Transition du Capitalisme: Exode du Travail Productif et Externalités. In Vers un Capitalisme Cognitif, edited by Christian Azaïs, Antonella Corsani, and Patrick Dieuaide, 135-152. Paris: L'Harmattan.

Brillouin, Léon. 1988. La Science et la Théorie de I'Information. Paris: Jacques Gabay.

Burawoy, Michael. 1979. Manufacturing Consent: Changes in the Labor Process under Monopoly Capitalism. Chicago: University of Chicago Press.

Castells, Manuel. 1998. La Societé en Réseaux. Paris: Fayard.

Chandler, Alfred. 1977. The Visible Hand: The Managerial Revolution in American Business. Cambridge, MA: Belknap Press.

Chesnais, François. 1996. A Mundialização do Capital. São Paulo: Xamã Editora.

Dantas, Marcos. 2014. As Rendas Informacionais e a Apropriação Capitalista do Trabalho Científico e Artístico. In A Informação e o Conhecimento sob as Lentes do Marxismo, edited by Rodrigo Moreno Marques, Filipe Raslan, Flávia Melo, and Marta Macedo K. Pinheiro, 35-60. Rio de Janeiro: Garamond.

Dantas, Marcos. 2012. Trabalho com Informação: Valor, Apropriação, Acumulação nas Redes do Capital. Rio de Janeiro: CFCH-UFRJ. Accessed 8 August 2017. http://marcosdantas.com.br/conteudos/2016/03/04/trabalho-com-informacao-valoracumulacao-apropriacao-nas-redes-do-capital/

Dantas, Marcos. 2011. Milionários Nada por Acaso: Capital Rentista e Apropriação do Trabalho Artístico nas Redes do Espetáculo. Eptic Online 13 (2): 1-30. Accessed 26 August 2017. https://seer.ufs.br/index.php/eptic/article/view/117

Dantas, Marcos. 2007. Os Significados do Trabalho: Produção de Valores como Produção Semiótica no Capitalismo Informacional. Trabalho, Educação e Saúde 5 (1): 9-50. Accessed 26 August 2017. http://www.marcosdantas.com.br/conteudos/2013/04/07/ossignificados-do-trabalho-producao-de-valores-como-producao-semiotica-no-capitalismoinformacional-trabalho-educacao-e-saude-v-5-n-1-2007/

Dantas, Marcos. 2001. Os Significados do Trabalho: Uma Investigação Semiótica no Processo de Produção. Doctoral Thesis. Rio de Janeiro: COPPE-UFRJ.

Dantas, Marcos. 1999. Capitalismo na Era das Redes: Trabalho, Informação e Valor no Ciclo da Comunicação Produtiva. In Informação e Globalização na Era do Conhecimento edited by Helena Lastres and Sarita Albagli, 216-261. Rio de Janeiro: Campus.

Dantas, Marcos. 1996. Valor-trabalho, Valor-informação. Transinformação 8 (1): 55-88.

Debord, Guy. 1977/1967. The Society of Spectacle. Marxists Internet Archive. Accessed 27 August 2017. https://www.marxists.org/reference/archive/debord/society.htm

Dejours, Christophe. 1995. Le Facteur Humain, Paris: Presses Universitaires de France.

Duarte, Francisco. J. C. M. and Vera Feitosa. 1988. Linguagem e trabalho. Rio de Janeiro: Lucerna.

Eco, Umberto. 1981/1973. O signo. Lisboa: Editorial Presença.

Eco, Umberto. 1976/1968. A Estrutura Ausente. São Paulo: Perspectiva.

Escarpit, Robert. 1991. L'Information et la Communication. Paris: Hachette Livre.

Evangelista, Rafael. 2007. Mais-valia 2.0. A Rede no 28, 2007/08. Accessed 23 January 2017. http://www.revista.arede.inf.br/site/edicao-n-28-agosto-2007/3762-mais-valia-2-0

Flichy, Patrice. 1991. Une Histoire de la Communication Moderne: Espace Public et Vie Privée. Paris: La Découverte.

Fontenelle, Isleide. 2002. O Nome da Marca: McDonald's, Fetichismo e Cultura Descartável. São Paulo: Boitempo.

Gorz, André. 2003. L'Immatériel: Connaissances, Valeur et Capital. Paris: Galilée.

Harvey, David. 2013. A Companion to Marx's Capital, Volume 2. London: Verso.

Harvey, David. 1996. Condição Pós-Moderna. São Paulo: Loyola.

Heilbroner, Robert L. 1988. Behind the Veil of Economics. New York: W. W. Norton.

Hobsbawm, Eric. 1997. A Era das Revoluções. São Paulo: Paz \& Terra.

Huet, Armel, Jacques lon, Alain Lèfebvre, Bernard Miège and René Peron. 1978. Capitalisme et Industries Culturelles. Grenoble: Presses Universitaires de Grenoble. 
Galbraith, John K. 2004. The Economics of Innocent Fraud: Truth for Our Time. Boston, MA: Houghton Mifflin.

Galbraith, John K. 1992. The Culture of Contentment. Boston, MA: Houghton Mifflin.

Galbraith, John K. 1967. The New Industrial State. Boston, MA: Houghton Mifflin.

Jameson, Frederic. 2006. Pós-Modernismo: A Lógica Cultural do Capitalismo Tardio. São Paulo: Atica.

Jappe, Anselm. 2003. Les Aventures de la Marchandise - Pour une Nouvelle Critique de la Valeur. Paris: Denoël.

Kurz, Robert. 1993. O Colapso da Modernização: Da Derrocada do Socialismo de Caserna à Crise da Economia Mundial. São Paulo: Paz \& Terra.

Landes, David S. 1994/1969. Prometeu Desacorrentado. Rio de Janeiro: Editora Nova Fronteira.

Lima, Isabelle M. 2005. Ceará Vira Pólo Exportador de Grifes de Luxo. Folha de S. Paulo, 15 November.

Lucas, Yvette. 1974. Codes et Machines: Essai de Sémiologie Industrielle. Paris: Presses Universitaires de France.

Marx, Karl. 1997/1885. Capital, Volume 2. Marx-Engels Archive, transcribed by Doug Hockin and Marxists Internet Archive volunteers. Accessed 26 August 2017. https://www.marxists.org/archive/marx/works/download/pdf/Capital-Volume-II.pdf

Marx, Karl. 1996/1867. Capital, Volume 1. Marx-Engels Archive, translated by Samuel Moore and Edward Aveling; edited by Frederick Engels; transcribed by Zodiac, Hinrich Kuhls,

Allan Thurrott, Bill McDorman, Bert Schultz and Martha Gimenez. https://www.marxists.org/archive/marx/works/download/pdf/Capital-Volume-I.pdf, Accessed August 26, 2017 /

Marx, Karl. 1973. Grundrisse: Foundations of the Critique of Political Economy (Rough Draft). London: Penguin.

Marx, Karl. 1864. The Process of Production of Capital, Draft Chapter 6 of Capital. Online version. https://www.marxists.org/archive/marx/ works/1864/economic/ ch02b.htm

Marx, Karl. 1844. Private Property and Communism. Economic and Philosophic Manuscripts of 1844. Marx-Engels Archive. Accessed 26 August 2017.

https://www.marxists.org/archive/marx/works/download/pdf/Capital-Volume-II.pdf

Marsden, Chris, Jonathan Cave. Edward Nason, Andrew Parkinson, Colin Blackman and Jason Rutter. 2006. Assessing Indirect Impacts of the EC Proposals for Video Regulation. Santa Monica, CA/EUA: Rand Corp. Accessed 26 August 2017. https://www.rand.org/content/dam/rand/pubs/technical reports/2006/RAND TR414.pdf

Mills, C. W. 1951. White Collar: The American Middle Classes. Oxford: Oxford University Press.

Moles, Abraham. 1978. Teoria da Informação e Percepção Estética, Rio de Janeiro: Tempo Brasileiro.

Monod, Jacques. 1976. O Acaso e a Necessidade. Petrópolis: Vozes.

Naville, Pierre. 1963. Vers l'Automatisme Social? Problèmes du Travail et de l'Automation. Paris: Gallimard.

Noble, David. 1984. Forces of Production: A Social History of Industrial Automation. Oxford: Oxford University Press.

Noble, David. 1979. America by Design. Oxford: Oxford University Press.

Peirce, Charles S. 1977/1931-1934. Semiótica. São Paulo: Perspectiva.

Prado, Eleutério. 2005. Desmedida do Valor. São Paulo: Xamã.

Prigogine, llya and Isabel Stengers. 1993. Ordem e Desordem, Enciclopédia Einaudi 26: "Sistema". Lisboa: Imprensa Nacional/Casa da Moeda.

Prigogine, llya and Isabel Stengers. 1988. Entre le temps et l'eternité, Paris: Fayard.

Rasmussen, Jens. 1986. Information Processing and Human-Machine Interaction: An

Approach to Cognitive Engineering. New York: Elsevier.

Rullani, Enzo. 2000. Le Capitalisme Cognitif: Du Déjà Vu? Multitudes 2: 87-94. 
Samuel, Raphael. 1992. Mechanization and Hand Labour in Industrializing Britain. In The Industrial Revolution and Work in Nineteenth-Century Europe, edited by Lenard

Berlanstein. 26-43. London: Routledge.

Saussure, Ferdinand. 1969/1916. Curso de linguística geral. São Paulo: Cultrix.

Scholz, Trebor, ed. 2013. Digital Labor: The Internet as Playground and Factory. New York: Routledge.

Sfez, Lucien. 1992/1988. Critique de la Communication. Paris: Le Seuil.

Shannon, Claude. 1948. A Mathematical Theory of Communication. The Bell System Technical Journal 27 (3): 379-423.

Sibilia, Paula. 2008. La intimidad como espectáculo. Buenos Aires: Fondo de Cultura Económica

Singh, Jagjit. 1982/1966. Teoría de la Información, del Lenguage y de la Cibernetica. Madrid: Alianza Universidad.

Smythe, Dallas W. 1977. Communications: Blindspot of Western Marxism. Canadian Journal of Political and Social Theory 1 (3): 1-27.

Tapscott, Don and Anthony Williams. 2006. Wikinomics: How Mass Collaboration Changes Everything. London: Portfolio Penguin.

Vianna, Hermano. 2011. Jardins Murados. O Globo, 29 June.

Vieira Pinto, Álvaro. 2005. O Conceito de Tecnologia. Rio de Janeiro: Contraponto.

Volochinov, Valentin. 2017/1929. Marxismo e Filosofia da Linguagem. São Paulo: Editora 34.

von Foerster, Heinz. 1980. Epistemology of Communication. In The Myths of Information: Technology and Post-Industrial Culture, edited by Kathleen Woodward, 18-27. London: Routledge \& Keegan-Paul.

Wiener, Norbert. 1950. The Human Use of Human Beings. Boston, MA: Houghton Mifflin Co. Wilden, Anthony. 2001. Informação. Enciclopédia Einaudi 34: "Comunicação-Cognição". Lisboa: Imprensa Nacional-Casa da Moeda.

Witt, Stephen. 2015. Como a Música Ficou Grátis. Rio de Janeiro: Intrínsica.

Zallo, Ramón. 1988. Economia de la Comunicación y de la Cultura. Madrid: Akal.

Zarifien, Philippe. 1996. Travail et Communication. Paris: Presses Universitaires de France.

\section{About the Author}

\section{Marcos Dantas}

Marcos Dantas is Professor at the Communication School of the Federal University of Rio de Janeiro (ECO-UFRJ). He holds a doctorate (DSc) in Industrial Engineering from COPPEUFRJ. He is a researcher in the Communication and Culture Postgraduate Program at ECOUFRJ and in the Information Science Postgraduate Program at IBICT/ECO-UFRJ. He is also a member of the Brazilian Internet Steering Committee (CGI.br). He was also Planning and Budget Secretary of the Brazilian Ministry of Communication, the Distance Education Secretary of the Brazilian Ministry of Education, and member of the Consultative Commission of the National Telecommunications Agency. He is also a member of the Deliberative Council of Celso Furtado International Centre for Development and former President of the Latin Union of Information, Communication and Culture - Brazilian Chapter (ULEPICC-Br). Professor Dantas' most important books are A lógica do capital-informação (1996), Trabalho com informação (2012), and Comunicações, Desenvolvimento, Democracia (2013). Website: http://marcosdantas.pro.br/ 